\title{
Symbol and Satire in the History of Restoration: Focusing on the Cleaning Controversy
}

\author{
TAGUCHI, Kaori
}

\begin{abstract}
The restoration of modern era in Europe has always continued trying to regard intervention as an act which assures "glorious immutability" of the art. However, during the Cleaning Controversy in 1960s, acute discussion over the purpose, range, and significance of cleaning pictures, process of reckless interventions were rallied in caricatures on magazines, and the propriety of restoration was seriously questioned all over Europe. This paper reveals how restoration, including cleaning, has been represented by various images of ridicule in those days, and clarifies how the image of restoration were documented, and somehow politically used.
\end{abstract}

Keywords-Restoration, Conservation, Cleaning controversy, Documentation, Patina, Caricature, Cesare Brandi

\section{INTRODUCTION: RESTORATION, BEFORE AND AFTER}

In August 2012, the shocking 'restoration' of a work of art was covered in the media. At issue was the fresco Ecce Homo (Behold the Man) by the Spanish painter Elias Garcia Martinez, which was painted on a wall of the Santuario de Misericordia Church in Borja, Zaragoza Province, Aragon Autonomous Community, Spain. The media reported that, as a result of a restoration 'imbued with prayers to the Blessed Virgin Mary', by Cecilia Gimenez ( 82 years old), a parishioner who made frequent visits to the church, Ecce Homo looked markedly different from the original (see Fig. 1).

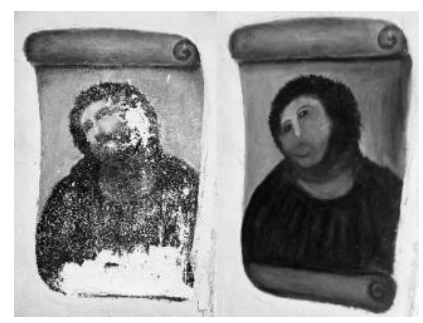

Fig.1 Elias Garcia Martinez Ecce Homo Before and after restoration, 2012

Before and after photographs showing the drastic changes made by the restoration graced the Spanish newspapers day after day. The uproar was not confined to Spain. A critical article was published in the Washington Post by reporter Olga Khazan that called the restoration 'wrongful, excessive vandalism', and Raphael Minder of the New York Times reported that it 'had left Jesus with a half-beard and, some say, a monkey-like appearance' [1]. On the web, the basics of the incident went viral in the blink of an eye, and the photograph of the painting became an object of mockery and led to unexpected artistic movements, such as the creation of a variety of collage photographs.

After that, the phenomenon showed developments that were even more interesting. As a result of the stampede of tourists trying to catch a glimpse of the Ecce Homo 'disaster', the painting had a totally unexpected economic effect, and it enriched the finances of the Santuario de Misericordia Church and the city of Borja. In fact, besides the $€ 1$ admission fee that the church collected from each visitor, there were copyright fees generated by products such as coffee mugs and T-shirts printed with the image of Jesus Christ after the restoration. After Borja's deputy mayor Juan Maria Ojeda announced the signing of a contract whereby Gimenez received 49 percent of the income from a copyright on the post-restoration Ecce Homo, with the remainder going to a foundation for the operation of the church, the 'restoration' by Gimenez was no longer a target of abuse; it had come to be treated as a 'product' for generating profits. The aftershocks from the restoration have not stopped. Gimenez had a one-woman art show, and in recent years, Americans Andrew Flick and Paul Fowler, librettist and composer, created the comic opera Behold the Man based on the sequence of events, which they plan to present in 2017, 'The 5th anniversary of the fresco's transformation' [2]. Meanwhile, to demonstrate the extent of the uproar, the descendants of painter Elias Garcia Martinez demanded that the painting be returned to its original condition. Antonio Val-Carreres, Ms. Gimenez's lawyer, explained that the profits would be used for charitable activities, and the situation is still full of complications and confusion, with no end in sight. In the midst of this series of events, the cartoon by Chris Madden, 'I prefer the restoration' [see Fig. 2], hints that one end of the process has been turned upside down.

Did the dramatically altered appearance of the painting due to restoration intervention merely add new value to an anonymous painting of its time, or is the 2012 interpretation that the restoration represented a violent change for the worse apt?

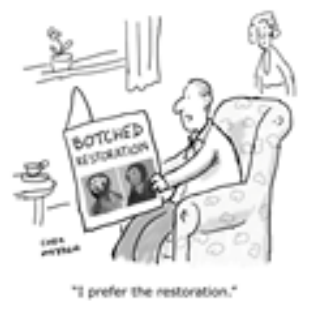

Fig. 2 Chris Madden 'I prefer the restoration', 2012 
In reality, Ecce Homo is not the first work of art whose before and after restoration images stirred up a large controversy and became the object of satire. Throughout the history of art, artworks have been significantly altered by conservation and restoration from time to time. This causes a shakeup not only in their artistic and historical value, but also in their economic value. Through this process, the temper of comments, concerns, and mockery of the danger spawned by acts of restoration has sometimes been expressed in the form of caricature.

The origin of the drawing of caricatures using abbreviated brushwork in order to make fun of things and events is very old [3], and its beginnings can be traced back to drawings of anthropomorphized birds and animals in ancient Egypt, written on pottery shards or papyrus [see Fig. 3].

In the West, caricatures depicting the selling of indulgences and mocking the hypocrisy of the Catholic Church became widely known from the Middle Ages onwards. In the 18th century, caricatures became more prevalent with the invention and development of lithography techniques. Caricatures were

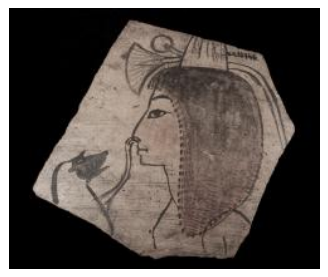

Fig. 3 Anonymous painting

'Opening mouth ritual' B. C. 1295-1068

disseminated quickly and in large volumes, and they became widely used for political messages and educational advertising. They would go on to claim an unshakable position in journalism. After the French daily satirical newspaper Le Charivari was founded, the satirical cartoon magazine Punch began publication in England in 1841. Many caricaturists such as John Leech emerged, and the magazine began publishing sketches lampooning incidents and situations in cities throughout the world, and primarily in London [4].

Within this context of the times, an incident of 'excessive intervention' at the London National Gallery beginning in 1846 stirred up controversy both inside and outside of England. What triggered this incident was the above-mentioned John Leech's caricature of a painting inside an art gallery that was being endangered by a violent cleaning method. Leech's caricature, while deforming its subject, simultaneously problematized the issues involved in conservation and restoration, which had not been made public at that time. Then, approximately 160 years later in Spain, an uproar surrounding restoration once again created a sensation in the press. The 'monkey-like' appearance created by the restoration took the form of caricatures and mascots and shook up public opinion, just as is touched on in the introduction.

This paper examines how acts of intervention, which have the potential to greatly alter the appearance of artwork, have been presented and what types of imagery have been used until the present time, using past emblems of conservation and restoration all the way up to modern caricatures and sketches as clues. Even though the collection of information pertaining to the appearance and structure of works of art before and after restoration is a common subject for the disciplines of conservation, restoration, documentation, and archival studies, there have been no specific studies of caricatures, etc., depicting conservation and restoration. John Leech's caricature The Cleaning Controversy is itself well known. In fact, there are many examples of its use as a reference, drawing in prior research related to cleaning. However, almost no examples exist of studies made of the cultural context of that period or related illustrations, either here or abroad [5].

The rest of the study attempts to restructure one aspect of the history of changing images of conservation and restoration, while at the same time filling in the gaps of prior research. This paper will lead to an outcome that will make clear the kinds of warning bells society has rung concerning the structures and images of artworks that have been lost due to irreversible interventions.

\section{II.GOLD RINGS AND FILMS OF PATINA: THE 16TH TO 18TH CEnTURIES}

How were acts of conservation and restoration represented in olden times, and how were they recorded? There are many paintings in existence that have an artist creating a work of art as their central figure, but we need to wait for the modern period for depictions of interventions themselves as the subject of artwork - and almost all of these are made public in the form of 'caricatures'. Nevertheless, symbols that signify 'conservation' were seen occasionally, starting from the 16th century. The painting Janus and Personified Eagle by Antonio Tempesta expresses the long-term 'preservation' and 'continuity' of a nation stabilized by wise government [See Fig. 4]. The god Janus raises aloft a ring, which signifies the turning of time and eternity.
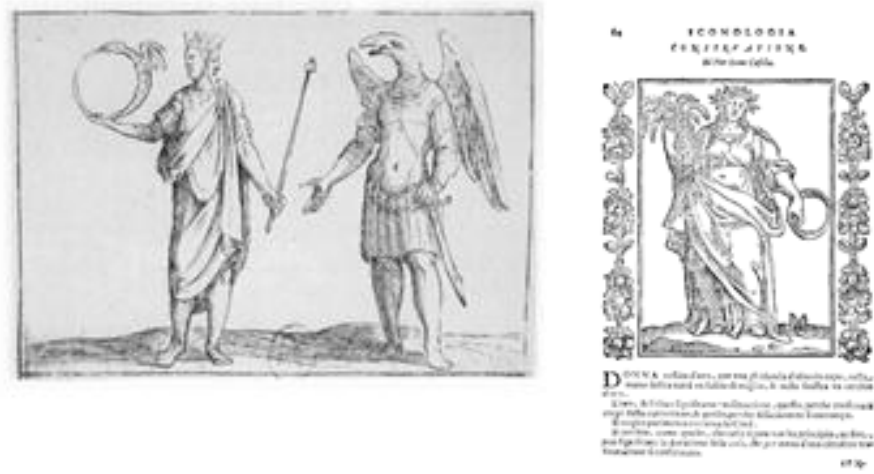

Fig. 4 (left) Antonio Tempesta

'Janus and Personified Eagle' XIVsec
Fig. 5 (right) Cesare Ripa 'Iconology of conservation' 1603
After that, in 1603, an allegory entitled 'Conservazione' appears in Iconologia, authored by Cesare Ripa and illustrated by Giuseppe Cesari, and as one would expect, time is depicted as a gold ring [See Fig. 5] signifying 'eternity' and 'durability', and the olive is included as a symbol meaning 'permanence.' One can sense from this picture that the lustre and robustness associated with gold at that time was the image given to 'conservation', and from the olive came peace and remoteness. However, one must keep in mind that the subject of the 
symbolic 'conservation' was assumed to be, not a work or art, but the nation. I would like to recall the The Reason of State (1590) written by Giovanni Botero, published contemporaneously to the above-mentioned symbols, in saying 'Change and loss are like the waxing and waning of the moon', explaining the importance of 'conservation', 'il conservare', of the creations of human beings. Against this historical backdrop, there are the circumstances under which symbols of conservation emerged within the political context [6]. However, at the same time, one must pay attention to the fact that until 2006, Ripa's allegory was used as the logo for Rome's Central Restoration Institute, which is charged with conservation and restoration of Italy's cultural properties. This demonstrates the fact that the allegory, originally painted with 'conservation of the nation' in mind, came to function as a symbol for the conservation of works of art.

In the 18th century, William Hogarth's Time Smoking a Picture (1761) [See Fig. 6] arrives on the scene as an important representation related to conservation and restoration.

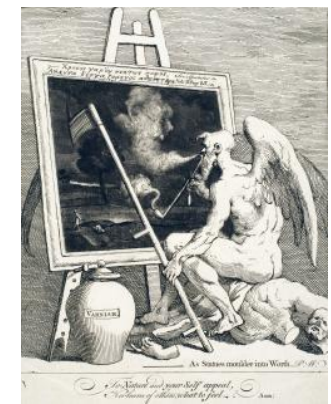

Fig. 6 William Hogarth

'Time Smoking a Picture', 1761

'Time', depicted in the previous paragraph as a gold ring, is expressed in Hogarth's work as causing noticeable deterioration of the work of art. In front of a single landscape painting, a person sprouting wings reminiscent of the 'eagle' depicted by Antonio Tempesta is unapologetically blowing tobacco smoke. However, what is portrayed here is anthropomorphized 'Time', and the smoke can be interpreted as damaging the work of art by clouding and muddling it. 'Time' is sitting on a smashed statue. With the scythe he is holding in his left hand, he is slashing vertical slits in the canvas on which the work is painted. One can see an epigram written in small Greek letters at the top of the drawing that says 'Time is not omnipotent, rather it weakens all things'. There is absolutely no mistake about it, 'Time' is depicted as the destroyer of works of art [Note 7].

However, the concept that the passage of time greatly mars the appearance of artworks takes a different turn after the arrival of the 19th century. The change in colour of the varnish applied to artworks and the thin veil on the surface created by the build-up of ashes and dust were prized as elements that lent paintings an ineffable antiquity and dignity and gave them a feeling of unity. The idea that it was none other than the passage of time itself that was the artist providing a final harmony to a work of art lead to the concept of 'time as an artist'. The art historian John Ruskin, a cultural influencer of the time, called the patina acquired by the coating of the painting over the course of aging a 'mellow tone' and praised it highly [8]. The art dealer Ambroise Vollard gives evidence that many artists at that time, beginning with Pierre-Auguste Renoir, believed in the effect of patina and thought that the passage of time would transform the artwork into an even greater work [9].

\section{VARNISH CLEANING AND VARNISH APPLICATION: THE 19TH CENTURY}

As mentioned in the introduction, the satirical magazine Punch began publication in 1841. In the history of conservation and restoration, 1841 was a deeply significant year, especially for the London National Gallery. This was three years before the appointment of Sir Charles Lock Eastlake, the second keeper of the collection. Additionally, right at that time, the London National Gallery began to consider doing a full-scale cleaning of the works in the collection.

In 1846, Eastlake resolved to undertake the removal and cleaning of the gallery varnish, the 'sweet brown patina' that had been applied to the works of art in the collections of the Gallery at that time, for the first time since the Gallery was opened. As a result, paintings such as Rubens' Peace and War, which had undergone excessive cleaning, attracted attention, and criticism was focused on the Gallery for purportedly damaging and erasing the original chromatic layer from the time the works were painted. A huge debate called 'The Cleaning Controversy' broke out, which drew in painters, art historians, and restorers. Of primary concern were the pros and cons of intervention on patina and the extent to which it should be done [Note 10]. The group of cleaned paintings were exhibited to the general public in 1846. In the twinkling of an eye, newspapers such as The Times began receiving letters opposing the cleaning. In 1847, the year following the uproar, the above-mentioned caricaturist John Leech published caricatures in Punch that made fun of London National Gallery employees cleaning higgledy-piggledy while running this way and that throughout the Gallery [See Fig. 7]. The work of restoration, which had been passed on as a 'secret art', with the details remaining hidden from ancient to modern times, was publicly exposed by this caricature as a collection of unmethodical methods that scarred the coating of the paintings more than was necessary [11].

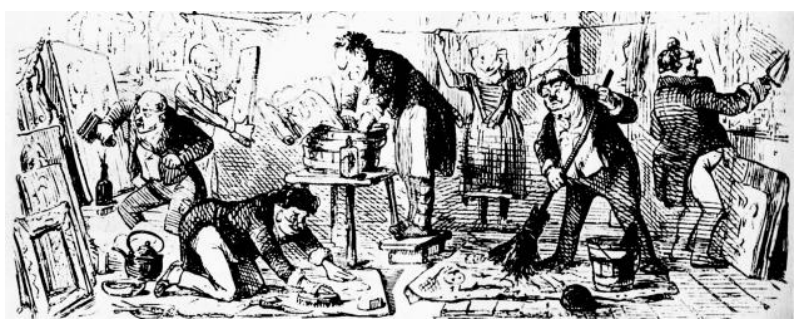

Fig. 7 John Leech 'Caricature of cleaning in National Gallery', 1947

Overblown expressions, such as those claiming the cleaning 'flayed' and 'scoured' the chromatic layers, plastered the pages of The Times. Leech faithfully expressed by means of caricatures the warnings issued from art historians and painters, but he drew with light and easy strokes. Bringing to mind Victoria-era housemaids, people are haphazardly sweeping paintings that are scattered over the floor with brooms. They are 
scrubbing them with brushes or kneading them in washtubs. There is no doubt that Leech's caricatures that ran in Punch, which had captured the majority of readers in its day, were a factor in the increase in mass interest directed at restoration. As attested to by researcher Frederick George Kitton, John Leech's success at Punch was dramatic, and very influential. No matter how his sketches dealt with topics and characters of interest of the time, they were not unnecessarily offensive. They were widely accepted and loved because of their characteristic warmth [12]. Eastlake, who felt the aftershocks of the cleaning controversy that had become widely known, not just among people in the art world, but also among the ordinary masses, was forced to make the decision to drastically reduce the number of paintings in the Gallery that were to be cleaned [13].

While Leech's caricatures were making fun of the excessive cleaning, Varnishing Day at the Royal Academy (1877), by the caricaturist George Du Maurier, focused on varnish that was applied in layers to works of art, not on the varnish that was being removed and stripped off. His scene of artists making the final touches in the name of restoration is of great interest [See Fig. 8].

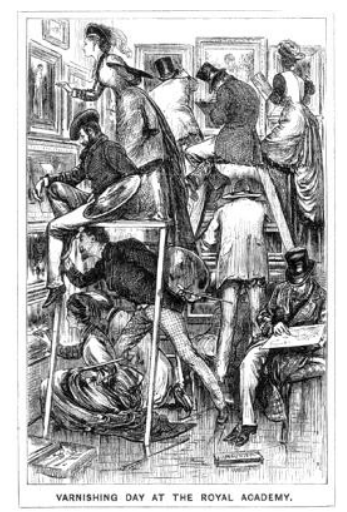

Fig. 8 George Du Maurier 'Varnishing Day at the Royal Academy' 1877

In the sketch, the artworks have already been hung on the wall and are on display. The artists are either standing on stepladders or sitting on the floor. In this cramped space, they are somehow or other guarding their own spot while hard at work making corrections and finishing touches to their work. At the Royal Academy, a day was set aside after artworks were displayed for artists to put the last finishing touches on them and to apply the final protective varnish: in other words, 'Varnishing Day'. This work is a valuable record of the scenes of Varnishing Day during that period, and at the same time, it functions as a caricature conveying the ridiculousness of the touch-up work performed by the painters.

In Western countries in the 19th century, it was not unusual for gallery varnish to be applied when a work came into a collection, for the probable purpose of creating a lustre on the entire canvas or to create a standardized look with a thick patina. Sometimes a number of layers of this amber coating were applied, the final result being to cloud the work's original chromatic layer, and at times shrouding it under an overly-thick coating. If one refers to the caricature mentioned in the previous section alongside 'Varnishing Day', an image will no doubt come to mind in which the group of paintings in the collections of 19 th century art museums are being subjected to dizzying iterations of applications and removals of coatings. Ulisse Forni, a restorer active in the 19th century, points to the fact that restorers at that time applied patina and dark varnish to hide the ineptness of their own techniques. However, looking at 'Varnishing Day', one cannot deny the possibility that these types of actions, as Forni declared, 'of persons taking on the task of cunningly trying to conceal bad work through the use of excessive patina, with sometimes devastating results on the work of art itself', were sometimes performed by the artists themselves [14]. It later became a barrier to the determination of the ages of paintings by appraisers and art historians, and the true character, and criminality, of the dark varnish that would come to be called the 'gallery varnish nightmare' has been communicated to us by means of the humorous expression of caricature.

The controversy surrounding cleaning heated up again from 1936 to 1947 , about 100 years after it first erupted in 1846 . The London National Gallery's Consultant Restorer, Helmut Ruhemann, who oversaw conservation and restoration, again cleaned many of the works in the collection, and because the patina was removed, once again voices gathered to criticize the Gallery's judgement. On this occasion, the conservation and restoration techniques were made public in a different fashion from the caricatures of John Leech. Keeping the previous criticism in mind, the Gallery determined that cleaning intervention carried out over approximately ten years was suitable, and as a result, in order to stress that the works had been returned to the sheen of the time of their creating, it presented a special exhibit called, 'Exhibition of cleaned paintings (1936-1947)'. At the same time as it displayed a total of 75 paintings, it presented the restoration process to the public. People had a valuable opportunity to see documentation of the intervention process, starting with the optical photography of the group of paintings. The aim of the National Gallery was to emphasize that all interventions, beginning with cleaning, were not carried out in a haphazard fashion using blind methods, such as those Leech had shown in his drawings half a century previously. Rather, they were carried out with extreme care after sufficiently understanding the structure of the work through accurate scientific investigation. However, their plans missed the mark, and in the 20th-century cleaning controversy, criticism that the restoration had greatly damaged the appearance of works of art was inevitable. The controversy continued to smoulder into the 1960 s in every country. it was in this context that the modern conservation and restoration pioneer Cesare Brandi published his Theory of Restoration in 1963, and the fact that he once again displayed the attitude of opposing the removal of 'patina' had no small influence [15].

In 1962, the newly-founded Private Eye magazine ran a photo-illustrated article making fun of cleaning at the London National Gallery:

Many people wonder why the paintings of Old Masters often have a dark, musty, and out-of-date look. The answer is simple. Because they were painted before the invention of electric light. But the coming of the new cleaning techniques, such as detergent and the vacuum cleaner, has changed all that. Many of the world's most famous 
galleries, including of course, our own London National Gallery, have taken advantage of Science to make their pictures as bright as new!

Underneath the article, there is a photograph of a man wrapped in a worker's coverall with a half-smile on his face, running a vacuum cleaner directly over a painting, with a caption saying, 'Restoration Intervention Step 4: The Cleaning Test' [See Fig. 9]. The article took the notices from the National Gallery announcing that they had made a study 'based on scientific judgement', were 'using the latest technologies', and furthermore, that they had cleaned 'scientifically', and reinterpreted them ironically. Compared to John Leech's Victorian-era sketch, here the image of the cleaning work performed casually as though it was household cleaning further emphasizes the danger. Furthermore, the article also quotes 'The eminent authority at the London National Gallery, Sir Filter Henpeck', as saying, 'Would you allow your home to remain uncleaned, year after year? Of course not'. It reports that the authorities think that, in the same way as a house is swept of dust, artworks must also be cleaned.

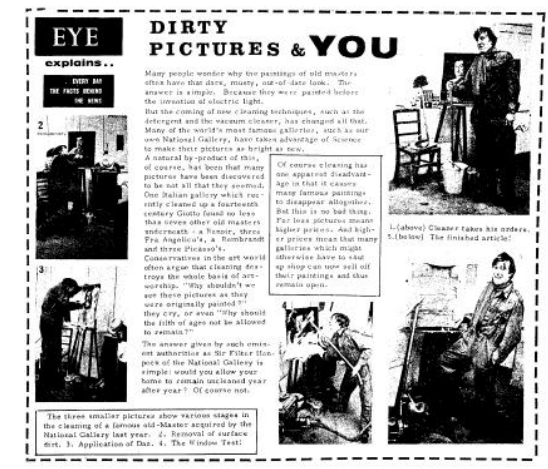

Fig. 9 'Restoration Intervention Step 4: The Cleaning Test', 1962

John Leech depicted scenes of varnish and colour being stripped through conservation and restoration with a humorous touch, George Du Maurier depicted a scene of varnish being applied by painters as a final adjustment, and Private Eye lampooned 'the latest' cleaning using machinery. Up until the 18th century, the image of conservation and restoration was represented in terms of gold rings symbolic of permanence and durability. In the modern era, triggered by the controversy surrounding cleaning, the image of behaviour destroying artworks coalesced and was made public as a caricature. In this way, the purpose and scope of restoration activity were problematized for the masses.

While keeping in mind the progress thus far, please turn your gaze to 1966, four years after the article in Private Eye. The actions of conservation and restoration were once again covered by media throughout the world. However, this time a more complex significance was attached to these actions.

\section{REPRESENTATION OF 'RESCUE' AND 'DOCUMENTATION'}

On November 4, 1966, in Florence, a long spell of continuous rain caused the Arno River to flood, and eventually a disaster of unparalleled seriousness occurred. In addition to the loss of many precious lives, Florence lost an enormous amount of valuable cultural properties. Eight hundred and fifty works of art were damaged (221 panel paintings, 413 works on canvas, and 23 manuscripts). Among them were world-famous art treasures, such as Crucifix by Cimabue at the Basilica of Santa Croce, Paolo Uccello's Creation of Adam at the Church of Santa Maria Novella, and Sandro Botticelli's St. Augustine and Domenico Ghirlandaio's St. Jerome at the Basilica of Ognissanti.

Many of the important changes visited on the disciplines of conservation and restoration and archival science in the West were initiated by the massive flood. Specific intervention techniques, beginning with cleaning and colour retouching, underwent a variety of changes, such as the floating board method devised for washing paper materials and the Astrazion Chromatica colour correction method (abstract colour interpolation technique) for reconstructing the chromatic layers with characteristic hues, etc. In addition, the re-evaluation of basic concepts of conservation and restoration, such as 'mass conservation' and 'preventive conservation', was triggered, and methods for the conservation and archiving of cultural properties also advanced swiftly. Through the recovery that took place after the disaster, Italy contributed to the advancement of the techniques and philosophy of conservation and restoration disciplines for the rest of the countries of the world.

Even now, as we reach the 50-year milestone of the flood, it is no mistake to claim that Crucifix by Cimabue is the work of art that shines as the symbol of the flood and the restoration [See Fig. 10].

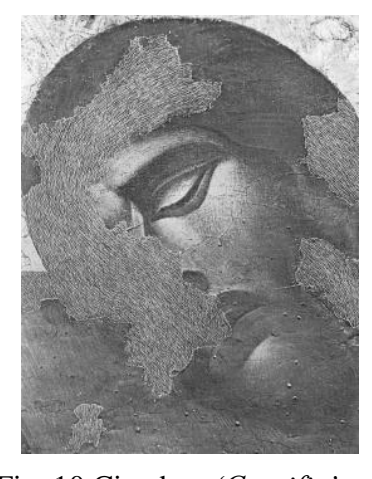

Fig. 10 Cimabue 'Crocifix' after restoration, 1976

This painting, which had lost 80 percent of its chromatic layer in the flood, was restored to its unique appearance by a colour correction method devised by art historian Umberto Baldini, who led the world of conservation and restoration in Florence at that time. The image of Christ, which had its missing areas filled in by a complex combination of four colours of brushstrokes, has to this day been the subject of inquiry from multiple viewpoints, on topics including the suitability of the technique and research on the remaining portions.

What this paper focuses on here is not the image of Crucifix, which was restored after being damaged, but the image that accompanied National Geographic's 1967 article entitled 'Florence Rises from the Flood' [See Fig. 11]. What was depicted was the scene inside the Uffizi Gallery on November 4, 1966, the day of the flood. At the right-hand edge of the scene is the bespectacled Baldini, mentioned above, who spearheaded restoration at the National Treasure Restoration Institute, 
holding on to the frame of a painting. Standing in dirty water up to his hips and trying to pass the painting to Baldini is the art historian Ugo Procacci, who at that time was responsible, along with Baldini, for the restoration of cultural properties in the province of Tuscany. The left-hand side of the drawing depicts workers persevering in saving the paintings in the same way. Standing on the stairs in the back, on the right, is a lone female is looking at Baldini and Procacci with a sad gaze. This gray-haired woman, the only one to appear in this sketch, is Dr. Luisa Becherucci, who was the Director of the Uffizi at that time.

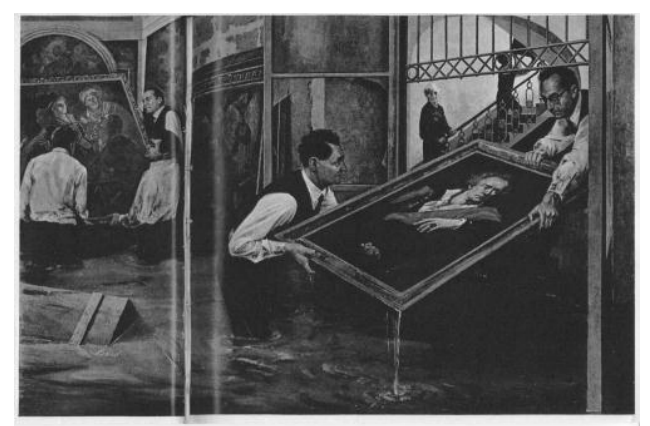

Fig. 11 National Geographic's article 'Florence Rises from the Flood', 1967

Becherucci is known as the person who had already, with the support of Procacci, begun working to save paintings that were stored inside the museum, starting from the night before the flood [16]. On the third day, when the city was gradually becoming inundated with water and the citizens were in a state of high anxiety, Becherucchi was most concerned about the collection lining the Vasari Corridor, a bridge connecting the Uffizi Gallery with the Pitti Palace. Becherucci was afraid that the bridge would collapse due to an inflow of dirty flood water and that the artworks would be destroyed. Procacci also had contacted her the night before and had directed her to 'take all possible measures' [17]. He firmly believed that it was worth taking every risk if there was a possibility of saving valuable cultural properties. Becherucchi, following Procacci's advice, moved dozens of artworks out of the danger zone. When the flood came, the waters rose to the foot of the bridge, but the bridge itself was spared from destruction. This meant that the Gallery itself was disastrously flooded.

The scenes described here of saving cultural properties, as with the caricatures referenced to this point, demonstrate a type of cultural conservation work 'act'. However, this sketch greatly differs from the examples in the previous section in that the scenes of the restorers at work depict them not as clearly damaging the artworks, but as carrying out appropriate measures in order to save and protect them. The dazzling image of 16th-century conservation and restoration built up by the allegory of 'shining gold rings', after passing through the years of turmoil concerning cleaning, once again was portrayed in a positive light, and took on even more narrative characteristics than ever before. That being said, why do the movements of all the people in this sketch leave a comical impression when we look at it? We see destroyed walls smashed into tiny pieces, flooded floors, and water dripping from masterpieces. Everything depicted in the picture conveys the stressful circumstances of the flood, but rather than the seriousness of the situation, what is oozing from the work is the comical bizarreness drifting from the story unfolding here.

In the piece-by-piece interplay of the image construction - the overly scrupulous human expression, the danger of the work of saving the artworks, the hidden ulterior motives of the characters - are hidden subtle distortions and comic elements, recognizable somehow as satire.

It is thought that this impression is brought on by the fact that the images of the characters engaged in salvaging works of art are functioning as a type of propaganda. The sketch, which spotlights the figures of Brandi and Procacci as heroes rescuing artwork from the flood waters, promotes once again the legitimacy of cultural property conservation and restoration work in Florence, which was already beginning to experience a cash-flow crunch one year after the flood, and filled an important role as 'advertising' material for the purpose of appealing widely for cooperation.

Immediately after the flood, Procacci obtained support from educational institutions in the United States, and established CRIA (Committee to Rescue Italian Art) with a core of researchers from Villa I Tatti in Italy (the Harvard University Center for Italian Renaissance Studies), creating an organization for long-term support for rescue, conservation, and restoration of works of art affected by the disaster. Procacci, the central figure in CRIA, minutely worked out the cash flow for the activities as well as the political balance of power concerning policies and rights of leadership. It was also Procacci's role to work out how to receive funding aid; how to maintain relationships with CRIA, which had dispatched teams of outstanding restorers from overseas; how to work with them; and, at times, how to ensure a necessary distance from them. CRIA created a list of artworks that needed restoration on a priority basis, and there was a risk that no timetable for restoration would be determined for cultural properties that did not make the list. It is known that by 1967 , there was already a downward trend in funding. The sketch of the salvaging scene depicted again under these circumstances backed up Procacci's assertion that the flood was not a past event; it was an evolving event occurring in the present, and it served as the impetus for letting the public know once again, via journalism, the full particulars of the heroic tale of how tragic the situation was at the time and just who it was that had 'physically' saved the artworks. In fact, the sketch was referenced in many places throughout Italy at the time, and when it ran in the special issue of National Geographic, it brought back vivid memories of that time.

In the history of the depiction of conservation and restoration, this sketch was one tool used politically to promote the legitimacy of the restorers' actions, completely removed from the satirical images protesting the actions of restorers. The calm gazes of the people depicted add the essence of 'humour', leading one to that conclusion.

\section{CONCLUSION: MULTI-LAYERED DISTORTION}

In the sketch recently published by the satirist Harris S., who said 'Artworks that were restored just last year were turned into landscapes even though they had been abstracts', even though 
restorers do not appear, the message that people engaged in restoration can potentially change works of art drastically is directly drawn [See Fig. 12].

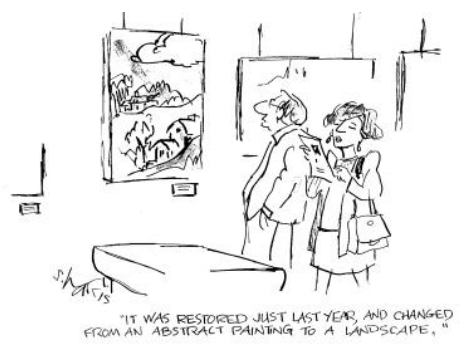

Fig. 12 Harris S. 'Artworks that were restored just last year were turned into landscapes even though they had been abstracts', 2012.

The word 'caricature', which means satirical drawing, comes from an Italian word meaning 'overloaded baggage' or 'distorted'. I would like to recall the fact that patina and varnish, which had been the main topic of debate during the cleaning controversy, really ought to be subject to removal as loads excessively accumulated on artworks and as sources of the distortion of these works. Modern satire about conservation and restoration is composed of a multi-layered distortion, which questions the world about a distorted phenomenon, and which is the distortion of the technique and theory of people intervening in elements thought to be distorting the work of art.

Forty years after the 1966 flood, Umberto Baldini was asked by Sandro Pintos, reporter at the Florence Art News, 'What method was the most critical for protecting cultural properties from the flood?' and he responded with the following: '...In any case, what was really important was to illustrate what had happened at that time, and to have a firm vision of what can happen to the existence of things in the human body'. Baldini said that no matter how valuable the cultural properties that were lost in the past, and no matter how great a shock it was, gradually-for better or for worse - one gets used to it. Baldini was giving more than a passing thought to a type of 'oblivion', and he was probably fixing his eye on the weakening sense of urgency that occurred with the passing of time after that day in 1966, when the specialists who had raced in to save the cultural properties gradually went back to their home countries, or perhaps the raw memories from the time of the cleaning controversy were still fresh in his mind [18].

The caricatures and sketches depicting the acts of conservation and restoration serve as a reminder of this 'oblivion', so to speak, and have been an unseen intervention that at times has remained out of the public eye. They mediate the acts of conservation and restoration that can only be seen through satirical expression, and we can renew our awareness of pieces of the historical processes through which works of art come to us from a special vantage point. While acknowledging the importance of recording the state of artworks themselves, the attempt to reconsider how much the aging process of artworks is looked upon as 'distorted' is an instructive guidepost for tracing the history of conservation and restoration.

\section{ACKNOWLEDGMENT}

I would like to gratefully and sincerely thank Dr. Michel Delay for his great help for finding important figures for this paper.

\section{REFERENCES}

[1] Khazan, Olga. "Spanish Woman Botches Ecche Homo Painting in an Attempt to Restore It" The Washington Post, August 232012 ; Minder, Raphael. "Despite Good Intentions, a Fresco in Spain is Ruined" the New York Times, August 24, 2012 ; Huerta, Rocío, "Restauradores profesionales tratarán de recuperar el eccehomo" El País, August 22 2012.

[2] Carvajal, Doreen. "Opera for a Ruined Fresco" the New York Times, August 16 2016, C3.

[3] Shimizu, Isao. Journey to Caricature in the World, Tokyo: Chuo-Koron-Sinsya, 1982.

[4] Huggett, Frank Edward. Victorian England as seen by Punch, London: Sidgwick and Jackson, 1978.

[5] Daley, Michael. "The museum world's increasing acceptance of virtual-reality resurrections" in Art Watch UK Online, $\mathrm{http} / / /$ artwatch.org.uk/the-museum-worlds-increasing-acceptance-of-vi rtual-reality-resurrections/, 2011

[6] Botero, Giovanni. Ragion di Stato (testo della prima edizione del 1589), a cura di Chiara Continisio, Collana Biblioteca n.23, Roma: Donzelli, 1997.

[7] Taguchi, Kaori. Technique and Philosophy of Restoration-Conservation, Tokyo: Heibonsya, 2015, pp. 25-30.

[8] Ibid.

[9] Vollard, Ambroise. La vie et l'œuvre de Pierre-Auguste Renoir, Paris: chez Ambroise Vollard, 1919.

[10] Taguchi, Op. cit., p. 26.

[11] Forni, Ulisse. Il manuale del pittore restauratore, Firenze: Le Monnier, 1866, pp. 105-108.

[12] Kitton, Frederic Geaorge. John Leech. Artist and Humorist: a Biological Sketch, London: George Redway, 1884, pp. 38-39.

[13] Jaynie, Anderson. "The First Cleaning Controversy at the National Gallery, 1846-1853" in Appearance, Opinion, Change: Evaluating the Look of the Painting, London: United Kingdom Institute of Conservation, 1960, p. 6.

[14] Forni, Op. cit., Ibid.

[15] Brandi, Cesare. La teoria del restauro, Torino: Einaudi, 1963.

[16] Clark, Robert. Dark Water, New York: Random House, a spread, 2009.

[17] AA.VV., Conservation Legacies of the Florence Flood of 1966, London: New York University, 2009, p. 170.

[18] Pintus, Sandro. Intervista a Umberto Baldini, Firenze Art News, 1996. 